\title{
PENERAPAN METODE K-MEANS PADA SISTEM INFORMASI AKADEMIK UNTUK PENGELOMPOKKAN SISWA BERPRESTASI DI UPT SMA NEGERI 3 KOTA PASURUAN BERBASIS WEB
}

\author{
Yudono Prayoga, Ali Mahmudi, Hani Zulfia Zahro' \\ Program Studi Teknik Informatika S1, Fakultas Teknologi Industri \\ Institut Teknologi Nasional Malang, Jalan Raya Karanglo km 2 Malang, Indonesia \\ 1718078@scholar.itn.ac.id
}

\begin{abstract}
ABSTRAK
Di dunia pendidikan saat ini dituntut untuk memiliki kemampuan bersaing dengan memanfaatkan sumber daya yang ada. selain sumber daya sarana, prasarana, dan manusia, sumber sistem informasi juga salah satu sumber daya yang digunakan untuk meningkatkan kemampuan bersaing. Pada saat ini prestasi siswa dipengarhui beberapa faktor diantaranya faktor akademik, dimana pada faktor akademik ini memiliki beberapa prasyarat untuk mendapatkan nilai rapor bagus dimana terdapat nilai pengetahuan, nilai keterampilan, dan nilai absensi. pada penelitian ini penulis ingin menerapan metode $\mathrm{k}$ means clustering pada sistem informasi akademik sma negeri 3 kota pasuruan untuk mengelompokkan siswa berprestasi berbasis web. Dengan adanya Sistem Informasi Akademik ini dapat memudahkan untuk mengelompokkan siswa berprestasi menurut mata pelajaran yang ada. Metode $\mathrm{K}$ Means merupakan metode yang bertujuan untuk pengelompokkan yang berada di sekumpulan data yang diwakili oleh variabel $\mathrm{K}$, dimana vareiabel $\mathrm{K}$ merupakan jumlah cluster yang akan ditentukan. Pada penelitian ini penulis menggunakan 3 cluster yaitu siswa berprestasi, kurang berprestasi, dan tidak berprestasi. Pada hasil penelitian ini disimpulkan bahwa terdapat perbedaan antara perhitungan manual menggunakan software excell dengan perhitungan sistem dimana $89 \%$ sesuai serta $11 \%$ tidak sesuai dengan kinerja sistem, serta untuk pengujian browser yaitu pada Google Chrome 91.0.472.106 (official Build) (64), untuk Microsoft Edge 91.0.864.54 (Official Build) (64), dan Mozilla Firefox 89 dapat bekerja sesuai dengan yang diharapkan. Untuk pengujian pengguna sistem yang telah dilakukan, dapat disimpulkan 25 orang yang terdapat pada kuisioner $84 \%$ memilih setuju, $12 \%$ memilih kurang setuju, $4 \%$ memilih tidak setuju. Dengan adanya hasil ini maka dapat menghasilkan pengelompokkan siswa berprestasi dengan baik.
\end{abstract}

Kata Kunci : Kompetensi Dasar, K-means clustering, berprestasi, kurang berprestasi, tidak berprestasi

\section{PENDAHULUAN}

Dunia pendidikan saat ini dituntut untuk memiliki kemampuan bersaing dengan memanfaatkan semua sumberdaya yang sudah ada. Mulai dari sumber daya sarana, prasarana, dan juga manusia, serta sumber system informasi yang merupakan salah satu sumber daya yang digunakan untuk meningkatkan kemampuan bersaing dengan yang lain. Prestasi merupakan sebuah hasil yang telah dicapai oleh seseorang dalam melakukan sesuatu yang mereka lakukan. Siswa berprestasi adalah sebuah sebutan yang dimana siswa memiliki beberapa atau banyak yang memiliki keunggulan pada suatu kegiatan akademik atau non akademik dengan standar yang berbeda-beda.

Pada penelitian sebelumnya dari Fitri Larasati Sibuea dan Andy Sapta tentang Pemetaan Siswa Berprestasi menggunakan metode K-Means Clustering yang bertujuan unuk memetakan siswa berprestasi menggunakan variable NIS, Nama Siswa, Ekstrakulikuler, Nilai Tugas, Uts, Uas, dan jumlah ketidakhadiran. Pada penelitian itu memiliki beberapa perbedaan yaitu pada variable yang digunakan serta studi kasus, penulis mengacu pada system e-raport SMA Negeri 3 Pasuruan dimana mengacu pada Nilai Pengetahuan, Nilai Keterampilan, dan Absensi atau Ketidakhadiran untuk setiap mata pelajaran yang ada.
Melalui penelitian ini penulis menggagas penerapan metode K Means pada Sistem Informasi Akademik untuk pengelompokkan Siswa Berprestasi berbasis web dapat memudahkan untuk menentukan siswa berprestasi, kurang berprestasi, dan tidak berprestasi untuk setiap mata pelajaran. Dengan adanya penelitian ini dapat dikembangkan dengan menggunakan metode yang lain.

\section{TINJAUAN PUSTAKA}

\subsection{Penelitian Terdahulu}

Fitri Larasati Sibuea, \& Andy Sapta (Desember 2017) tentang "Pemetaan Siswa Berprestasi menggunakan metode K-Means Clustering". Tujuan dari penelitian ini yaitu memetakan siswa berprestasi menggunakan metode $K$-Means Clustering dengan menggunakan atribut yang dijadikan variable terdiri dari NIS, Nama, Ekstrakulikuler, Nilai Tugas, UTS, UAS, dan Jumlah Ketidakhadiran. [1]

Tedy Rismawan, \& Sri Kusumadewi (Juni 2008) tentang "Aplikasi K-Means untuk Pengelompokan Mahasiswa berdasarkan Nilai Body Mass Index (BMI) \& ukuran kerangka”. Tujuan dari penelitian ini yaitu membangun aplikasi untuk mengelompokkan mahasiswa berdasarkan nilai BMI dan kerangka menggunakan metode klasifikasi $K$ Means.[2] 


\subsection{Metode K-Means Clustering}

Means merupakan suatu algoritma pengklasteran yang cukup sederhana yang mempartisi databest kedalam beberapa clasteran k. Algoritma ini cukup mudah untuk diimplementasikan dan dijalakan, relatif cepat, mudah disesuaikan dan banyak digunakan (Wu \& Kumar, 2009). Prinsip uatama dari teknik ini adalah menyusun $\mathrm{K}$ buah partisi/pusat massa (centroid)/rata-rata (mean) dari sekupulan data. Algoritma K-Means dimulai dengan pembentukan partisi klaster diawal kemudian secara iteraktif partisi claster ini diperbaiki hingga tidak terjadi perubahan yang signifikan pada partisi claster (Written, 2011).

Langkah-langkah dalam algoritma K-Means:

a. Identifikasikan data yang akan dikelompokkan dan tentukan cluster data, Xij (I =1,2...n; $\mathrm{j}=1,2, \ldots . \mathrm{m})$ dimana $\mathrm{n}$ adalah jumlah data yang akan di cluster dan $\mathrm{m}$ adalah jumlah variabel data

b. Awal iterasi pusat setiap cluster ditentukan dengan cara acak.

c. Tentukan jarak setiap data dengan pusat cluster menggunakan rumus Euclidean berikut :

$$
d\left(x_{i}, u_{i}\right)=\sqrt{\left(x_{i}, u_{i}\right)^{2}} \text { Persamaan } 1
$$

d. Kelompokkan data berdasarkan jarak terdekat data terhadap pusat centroid awal

e. Selanjutnya cari pusat cluster baru dengan menghitung pusat cluster berdasarkan nilai ratarata dengan rumus :

$$
C_{k}=\frac{1}{n_{k}} \sum d_{i} \quad \text { Persamaan } 2
$$

Dimana nk adalah jumlah data dalam cluster Di jumlah dari nilai jarak yang masuk dalam masing-masing cluster

f. Cek kondisi apakah pusat cluster berubah jika ya maka iterasi dilanjutkan dan hitung ulang masingmasing data terhadap nilai cluster baru

g. Jika tidak terdapat perbedaan pada pusat cluster baru dan lama maka iterasi dihentikan.

\section{METODE PENELITIAN}

Dalam penelitian ini penulis menggunakan metode penelitian sebagai berikut :

1. Studi Literasi

Pada tahap ini penulis mengumpulkan data serta mencari data melalui sumber-sumber seperti jurnal, tutorial, maupun bacaan.

2. Pengumpulan data dan Analisis

Pengumpulan data dengan meminta data berupa nilai-nilai secara langsung terhadap pihak-pihak yang berkaitan dengan penelitian ini yang difungsikan sebagai metode untuk melakukan penjelasan langsung terhadap data-data yang dipelajari.

3. Clustering

Clustering adalah salah satu teknik dari fungsionalitas data mining, algoritma clustering merupakan algoritma pengelompokkan sejumlah data tertentu (cluster). Setiap cluster memiliki centroid atau rata-rata nilai tiap anggota dari satu cluster dan memiliki medoid yang merupakan anggota yang letaknya berada tepat ditengah. Sementara jarak antar cluster didefinisikan dengan menggunakan beberpa metode untuk menentukan cluster mana yang berdekatan. (Kusrini,2009)

4. Analisa dan Perancangan Sistem

Pada tahap ini dilakukan perancangan system dimana dapat mempermudah guru atau pengajar untuk mengolah nilai serta mencari siswa berprestasi dikelas tertentu. Dan untuk hasil pengolahan data nilai mulai dari input sampai hasil tersebut ditampilkan di wesite

5. Pembuatan Aplikasi

Pada tahapan ini dilakukan pembuatan aplikasi berbentuk website dengan menggunakan pemrograman HTML, CSS, PHP, serta untuk penyimpanan dalam bentuk database menggunakan MySQL.

\subsection{Blog Diagram Sistem}

Untuk guru dapat mengakses halaman untuk input data siswa berupa nilai pengetahuan, nilai keterampilan, dan absensi. Kemudian data tersebut disimpan di database. Proses selanjutnya yaitu perhitungan data menggunakan metode K-Means, setelah hasil dari perhitungan tersebut dikelompokkan berdasarkan siswa berprestasi, kurang berprestasi, tidak berprestasi. Kemudian data tersebut ditampilkan dan disimpan di dalam database

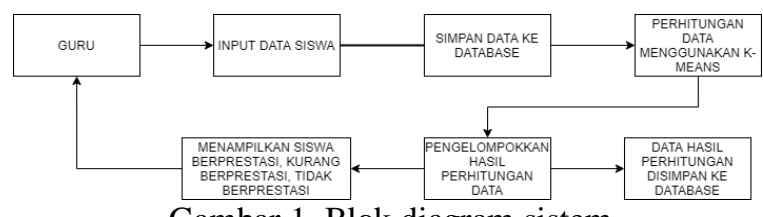

Gambar 1. Blok diagram sistem

\subsection{Flowchart Sistem}

Flowchart sistem ini menjelaskan proses berjalananya aplikasi seperti ditunjukkan pada Gambar 2

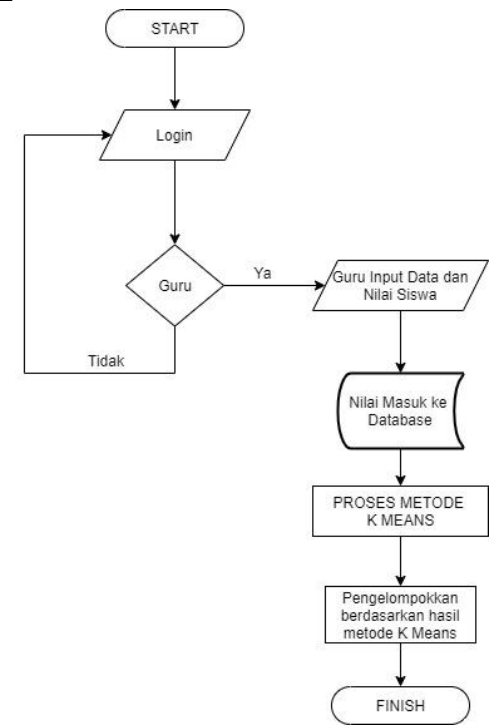

Gambar 2. Flowchart Sistem 
Seperti pada flowchart diatas dapat dijelaskan bahwa pada halaman login guru mengisi username dan password dengan benar maka masuk ke halaman guru, jika salah maka kembali ke halaman login. Setelah masuk ke halaman utama guru, guru dapat input absensi siswa mulai dari kelas mana beserta nama-nama anggota kelas tersebut. Jika telah mengisi absensi siswa, guru dapat memberi nilai-nilai yang nanti dijabarkan menjadi nilai pengetahuan dan nilai keterampilan, untuk nilai pengetahuan dan nilai keterampilan ditentukan berdasarkan Kompetensi Dasar (KD) yang dimana untuk setiap guru mata pelajaran memiliki sistem penilaian KD yang berbeda-beda, untuk penelitian ini menggunakan data satu kelas XI MIPA-1 semester ganjil untuk mata pelajaran bahasa Jerman dimana menggunakan $6 \mathrm{KD}$ untuk pengetahuan yang dibagi mulai dari tugas dan ulangan harian dan $6 \mathrm{KD}$ untuk keterampilan. Setelah perhitungan pada setiap KD maka didapatkan nilai untuk nilai pengetahuan dan nilai keterampilan yang kemudian masuk ke dalam database untuk melakukan proses berikutnya. Proses berikutnya yaitu pada metode $K$-Means untuk melakukan perhitungan mulai dari penentuan cluster hingga pengelompokkan data berdasarkan cluster, kemudian pengelompokkan dibagi antara siswa berprestasi, siswa kurang berprestasi, dan siswa tidak berprestasi.

\section{HASIL DAN PEMBAHASAN}

Implementasi sistem adalah proses dimana sistem mulai diimplementasikan untuk dijadikan sebuah aplikasi berbasis web. Pada pengujian dijelaskan hasil dari Penerapan Metode K-Means pada Sistem Informasi Akademik untuk Pengelompokkan siswa berprestasi. Setelah itu hasil uji coba akan dilakukan analisis untuk menacpai tujuan telah dipaparkan.

\subsection{Tampilan Halaman Awal}

Pada halaman website akan pesan selamat datang dengan menu side bar seperti pada gambar 3 .

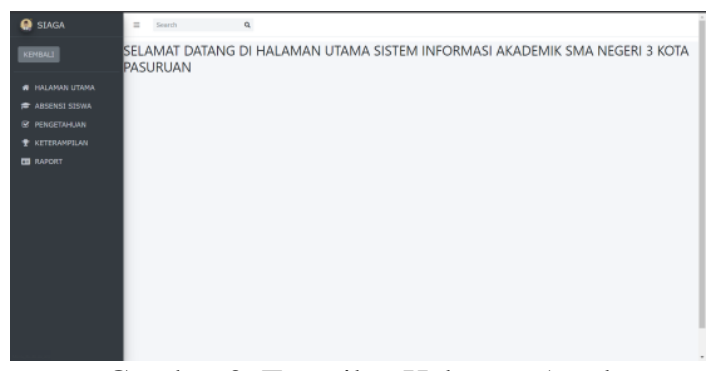

Gambar 3. Tampilan Halaman Awal

\subsection{Halaman Pengetahuan}

Pada halaman ini terdapat beberapa data penilaian pengetahuan yang berisikan daftar siswa dengan penilaian pengetahuan seperti pada gambar 4 . Untuk membuat data penilaian pengetahuan baru seperti pada gambar 4.3 , sedangkan untuk mengubah data penilaian pengetahuan seperti pada gambar 6

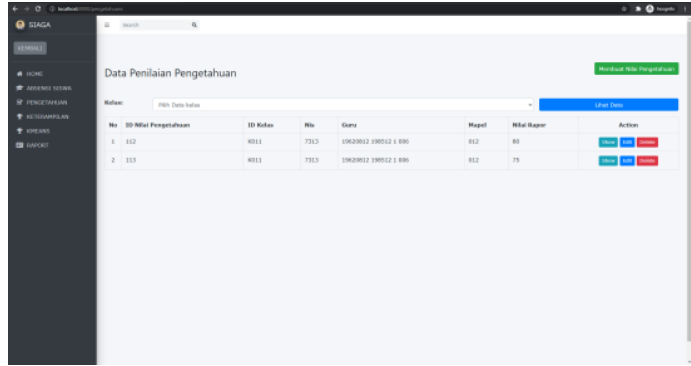

Gambar 4. Halaman Index Pengetahuan

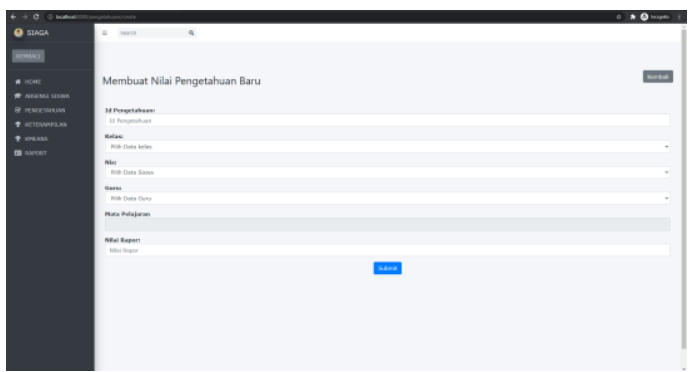

Gambar 5. Halaman Menambah Data Nilai Pengetahuan

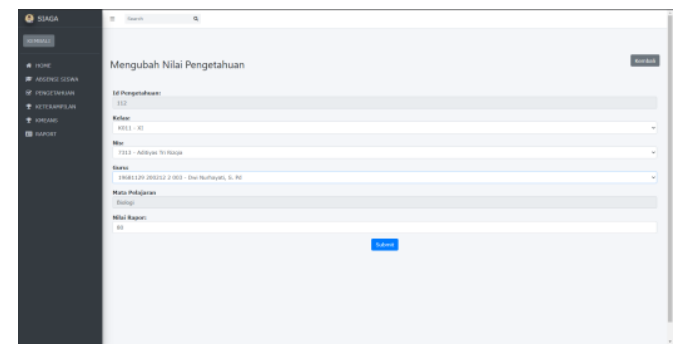

Gambar 6. Halaman Mengubah Data Nilai Pengetahuan

\subsection{Halaman Keterampilan}

Pada halaman ini sama seperti halaman pengetahuan dimana terdapat beberapa data penilaian keterampilan yang berisikan daftar siswa dengan penilaian keterampilan seperti pada gambar 7, sedangkan untuk membuat nilai keterampilan baru terdapat pada gambar 8 dan untuk mengubah nilai keterampilan terdapat pada gambar 9

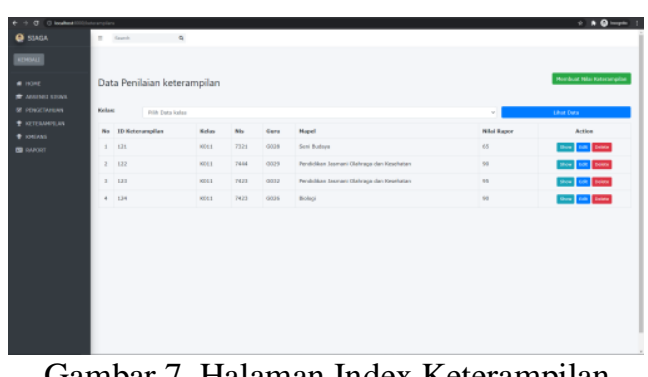

Gambar 7. Halaman Index Keterampilan 


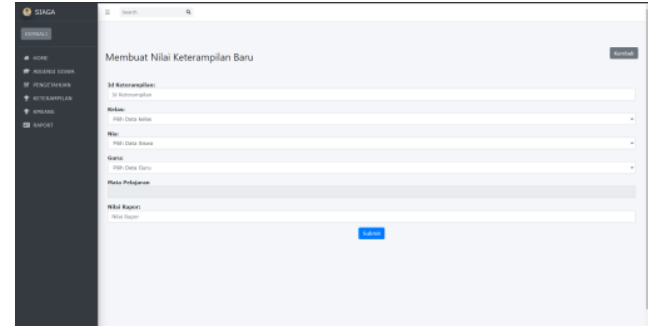

Gambar 8. Halaman Membuat Data Nilai Baru

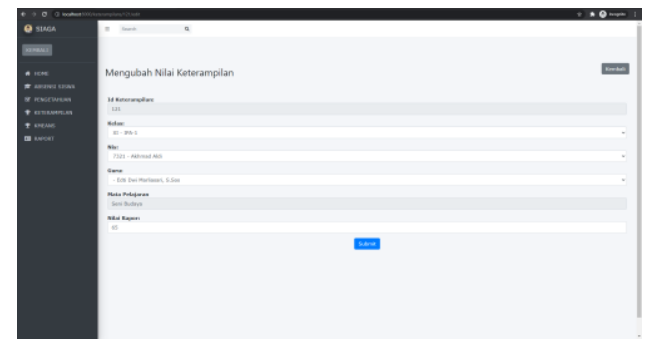

Gambar 9. Halaman Mengubah Nilai Keterampilan

\subsection{Halaman $K$ Means}

Pada halaman ini terdapat daftar penilaian $\mathrm{K}$ Means yang dimana daftar siswa yang ingin di proses dengan metode $\mathrm{K}$ Means dengan menggabungkan nilai absensi, nilai keterampilan, dan nilai pengetahuan yang ditunjukkan pada gambar 10. Serta untuk perhitungan lengkapnya dapat dilihat pada gambar 11

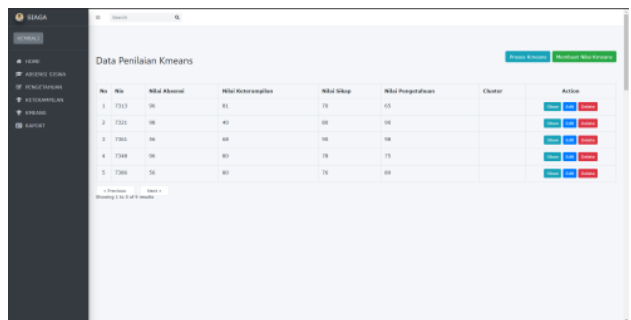

Gambar 10. Halaman Penilaian Metode K Means

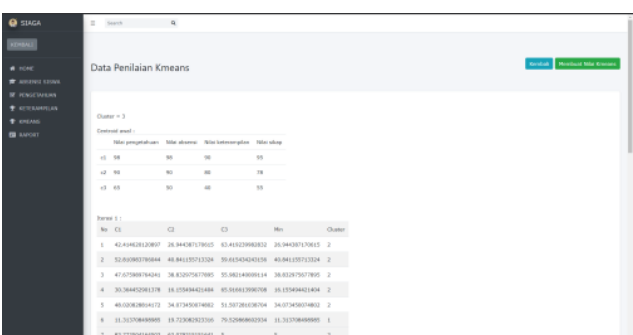

Gambar 11. Halaman Proses Perhitungan Metode K Means

\subsection{Halaman Raport}

Pada halaman ini berupa report untuk menjadi pelaporan dimana berisikan daftar per siswa yang memiliki nilai raport seluruh mata pelajaran yang telah diikuti sebelumnya yang di visualisasikan pada gambar 12 dan hasil raport dapat di tampilkan pada gambar 13 berupa bentuk pdf.

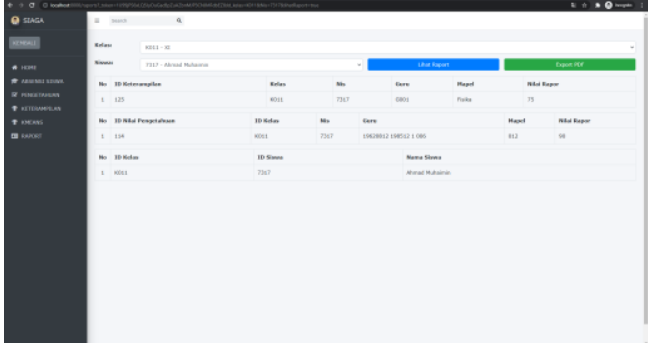

Gambar 12. Halaman Raport

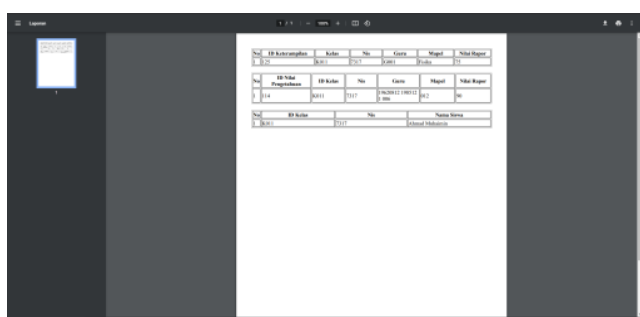

Gambar 13. Tampilan Raport Siswa

\subsection{Pengujian Metode}

Pada pengujian ini, perhitungan metode KMeans dilakukan pada studi kasus Siswa Kelas XIMIPA 1 Semester Ganjil pada SMA Negeri 3 Kota Pasuruan selaku pemilik data penelitian serta mata pelajaran Bahasa Jerman. Dengan langkah sebagai berikut :

1. Penentuan cluster pada penelitian ini dilakukan diawal yakni terdapat 3 cluster yang akan dijadikan tempat untuk mengelompokkan siswa yaitu:
a. Cluster 1
b. Cluster 2
c. Cluster 3

2. Penentuan centroid awal pada penelitian ini dilakukan secara acak dengan memilih 3 data

Tabel 1. nilai centroid

\begin{tabular}{|l|r|r|r|}
\hline Cluster 1 & 100 & 80 & 83 \\
\hline Cluster 2 & 85 & 77 & 77 \\
\hline Cluster 3 & 65 & 70 & 74 \\
\hline
\end{tabular}

3. Menentukan data acak ke dalam cluster dan menentukan jarak setiap data yang ada terhadap setiap pusat cluster dimana hasil perhitungan keseluruhan data akan disajikan pada tabel 2 berikut

Tabel 2. Hasil perhitungan jarak pada masing-masing centroid

\begin{tabular}{|c|c|c|c|}
\hline C1 & C2 & C3 & Jarak Terdekat \\
\hline 13.2 & 6.5 & 25.5 & 6.5 \\
\hline 35.4 & 20.0 & 8.9 & 8.9 \\
\hline 9.6 & 7.1 & 28.4 & 7.1 \\
\hline 7.1 & 15.2 & 35.6 & 7.1 \\
\hline 18.0 & 3.6 & 20.4 & 3.6 \\
\hline 3.6 & 15.3 & 36.4 & 3.6 \\
\hline 35.3 & 20.1 & 9.4 & 9.4 \\
\hline 18.4 & 4.4 & 19.7 & 4.4 \\
\hline 1.0 & 16.3 & 37.2 & 1.0 \\
\hline 28.5 & 13.1 & 11.4 & 11.4 \\
\hline 7.3 & 10.1 & 31.3 & 7.3 \\
\hline 5.4 & 15.1 & 36.1 & 5.4 \\
\hline 3.2 & 15.4 & 36.6 & 3.2 \\
\hline
\end{tabular}




\begin{tabular}{|c|c|c|c|}
\hline $\mathbf{C 1}$ & $\mathbf{C 2}$ & $\mathbf{C 3}$ & Jarak Terdekat \\
\hline 4.5 & 15.2 & 36.2 & 4.5 \\
\hline 5.0 & 15.3 & 36.6 & 5.0 \\
\hline 28.4 & 12.6 & 10.0 & 10.0 \\
\hline 16.2 & 8.8 & 25.0 & 8.8 \\
\hline 12.2 & 5.5 & 25.8 & 5.5 \\
\hline 16.6 & 2.2 & 21.0 & 2.2 \\
\hline 10.5 & 10.8 & 30.3 & 10.5 \\
\hline 9.9 & 7.1 & 28.2 & 7.1 \\
\hline 7.1 & 15.2 & 35.6 & 7.1 \\
\hline 9.3 & 10.2 & 30.6 & 9.3 \\
\hline 19.2 & 3.0 & 18.6 & 3.0 \\
\hline 5.0 & 15.1 & 36.0 & 5.0 \\
\hline 10.7 & 7.3 & 27.7 & 7.3 \\
\hline 4.5 & 15.2 & 36.2 & 4.5 \\
\hline 4.1 & 15.3 & 36.5 & 4.1 \\
\hline 15.9 & 1.4 & 21.9 & 1.4 \\
\hline 8.7 & 10.2 & 30.7 & 8.7 \\
\hline 7.1 & 15.2 & 35.6 & 7.1 \\
\hline 10.4 & 7.0 & 28.1 & 7.0 \\
\hline 4.2 & 15.3 & 36.2 & 4.2 \\
\hline 25.5 & 10.2 & 13.2 & 10.2 \\
\hline 8.7 & 10.2 & 30.7 & 8.7 \\
\hline \multicolumn{5}{|c}{} \\
\hline
\end{tabular}

4. Setelah menghitung jarak pada centroid, maka dilakukan pengelompokkan data yaitu pada tabel 3

Tabel 3. Hasil Pengelompokkan

\begin{tabular}{|c|c|c|c|c|}
\hline C1 & $\mathrm{C2}$ & C3 & Jarak Terdekat & $\begin{array}{c}\text { Penge- } \\
\text { lompokkan }\end{array}$ \\
\hline 13.2 & 6.5 & 25.5 & 6.5 & $\mathrm{c} 2$ \\
\hline 35.4 & 20.0 & 8.9 & 8.9 & c3 \\
\hline 9.6 & 7.1 & 28.4 & 7.1 & $\mathrm{c} 2$ \\
\hline 7.1 & 15.2 & 35.6 & 7.1 & $\mathrm{c} 1$ \\
\hline 18.0 & 3.6 & 20.4 & 3.6 & $\mathrm{c} 2$ \\
\hline 3.6 & 15.3 & 36.4 & 3.6 & $\mathrm{cl}$ \\
\hline 35.3 & 20.1 & 9.4 & 9.4 & c3 \\
\hline 18.4 & 4.4 & 19.7 & 4.4 & $\mathrm{c} 2$ \\
\hline 1.0 & 16.3 & 37.2 & 1.0 & $\mathrm{c} 1$ \\
\hline 28.5 & 13.1 & 11.4 & 11.4 & c3 \\
\hline 7.3 & 10.1 & 31.3 & 7.3 & $\mathrm{c} 1$ \\
\hline 5.4 & 15.1 & 36.1 & 5.4 & $\mathrm{c} 1$ \\
\hline 3.2 & 15.4 & 36.6 & 3.2 & $\mathrm{c} 1$ \\
\hline 4.5 & 15.2 & 36.2 & 4.5 & $\mathrm{c} 1$ \\
\hline 5.0 & 15.3 & 36.6 & 5.0 & $\mathrm{c} 1$ \\
\hline 28.4 & 12.6 & 10.0 & 10.0 & c3 \\
\hline 16.2 & 8.8 & 25.0 & 8.8 & c2 \\
\hline 12.2 & 5.5 & 25.8 & 5.5 & $\mathrm{c} 2$ \\
\hline 16.6 & 2.2 & 21.0 & 2.2 & $\mathrm{c} 2$ \\
\hline 10.5 & 10.8 & 30.3 & 10.5 & $\mathrm{cl}$ \\
\hline 9.9 & 7.1 & 28.2 & 7.1 & c2 \\
\hline 7.1 & 15.2 & 35.6 & 7.1 & $\mathrm{c} 1$ \\
\hline 9.3 & 10.2 & 30.6 & 9.3 & $\mathrm{c} 1$ \\
\hline 19.2 & 3.0 & 18.6 & 3.0 & $\mathrm{c} 2$ \\
\hline 5.0 & 15.1 & 36.0 & 5.0 & $\mathrm{c} 1$ \\
\hline 10.7 & 7.3 & 27.7 & 7.3 & $\mathrm{c} 2$ \\
\hline 4.5 & 15.2 & 36.2 & 4.5 & $\mathrm{c} 1$ \\
\hline 4.1 & 15.3 & 36.5 & 4.1 & $\mathrm{c} 1$ \\
\hline 15.9 & 1.4 & 21.9 & 1.4 & $\mathrm{c} 2$ \\
\hline 8.7 & 10.2 & 30.7 & 8.7 & $\mathrm{c} 1$ \\
\hline 7.1 & 15.2 & 35.6 & 7.1 & $\mathrm{c} 1$ \\
\hline 10.4 & 7.0 & 28.1 & 7.0 & c2 \\
\hline 4.2 & 15.3 & 36.2 & 4.2 & $\mathrm{c} 1$ \\
\hline 25.5 & 10.2 & 13.2 & 10.2 & $\mathrm{c} 2$ \\
\hline 8.7 & 10.2 & 30.7 & 8.7 & $\mathrm{c} 1$ \\
\hline
\end{tabular}

5. Setelah melakukan pengelompokkan data maka langkah selanjutnya yaitu menghitung kembali pusat cluster yang baru pada tabel 4

Table 4. Tabel Centroid Baru

\begin{tabular}{|l|l|l|l|}
\hline Cluster 1 & 84.5 & 65.9 & 67.5 \\
\hline Cluster 2 & 80.5 & 70.0 & 71.8 \\
\hline Cluster 3 & 69.3 & 76.0 & 77.3 \\
\hline
\end{tabular}

6. Setelah menentukan cluster centorid baru maka hal selanjutnya sama seperti pada langkah ke 2 pada iterasi berikutnya sehingga dihasilkan data yang baru sama dengan hasil pengelompokkan yang sebelumnya maka iterasi sudah dapat dihentikan, dalam penelitian ini sampai hingga iterasi ke-5, dimana setiap cluster tidak berubah dan tidak ada lagi data yang berpindah dari satu cluster ke cluster yang lainnya

Tabel 5. Hasil perbandingan perhitungan manual dan sistem

\begin{tabular}{|c|c|c|c|c|}
\hline \multirow[b]{2}{*}{ No } & \multirow[b]{2}{*}{ Nama } & \multicolumn{2}{|c|}{ Hasil Perhitungan } & \multirow[b]{2}{*}{$\begin{array}{c}\text { Hasil } \\
\text { perbandingan }\end{array}$} \\
\hline & & Manual & $\begin{array}{c}\text { Yang } \\
\text { terdapat } \\
\text { disistem }\end{array}$ & \\
\hline 1 & ATR & c2 & $\mathrm{c} 2$ & SAMA \\
\hline 2 & $\mathrm{AM}$ & $\mathrm{c} 3$ & $\mathrm{c} 3$ & SAMA \\
\hline 3 & AAM & $\mathrm{c} 2$ & $\mathrm{c} 2$ & SAMA \\
\hline 4 & AAL & $\mathrm{c} 1$ & $\mathrm{c} 1$ & SAMA \\
\hline 5 & AMW & $\mathrm{c} 2$ & $\mathrm{c} 2$ & SAMA \\
\hline 6 & $\mathrm{CZF}$ & $\mathrm{c} 1$ & $\mathrm{c} 1$ & SAMA \\
\hline 7 & DJA & c3 & c3 & SAMA \\
\hline 8 & DPR & c2 & c3 & BEDA \\
\hline 9 & FAR & $\mathrm{c} 1$ & $\mathrm{c} 1$ & SAMA \\
\hline 10 & FQN & $\mathrm{c} 3$ & $\mathrm{c} 3$ & SAMA \\
\hline 11 & FKA & $\mathrm{c} 1$ & $\mathrm{c} 3$ & BEDA \\
\hline 12 & FMA & $\mathrm{c} 1$ & $\mathrm{c} 1$ & SAMA \\
\hline 13 & KAN & $\mathrm{c} 1$ & $\mathrm{c} 1$ & SAMA \\
\hline 14 & KAU & $\mathrm{c} 1$ & $\mathrm{c} 1$ & SAMA \\
\hline 15 & LCA & $\mathrm{c} 1$ & $\mathrm{c} 1$ & SAMA \\
\hline 16 & MAS & $\mathrm{c} 3$ & $\mathrm{c} 3$ & SAMA \\
\hline 17 & MAY & $\mathrm{c} 2$ & $\mathrm{c} 2$ & SAMA \\
\hline 18 & MRK & $\mathrm{c} 2$ & $\mathrm{c} 2$ & SAMA \\
\hline 19 & MWE & $\mathrm{c} 2$ & $\mathrm{c} 2$ & SAMA \\
\hline 20 & MFA & $\mathrm{c} 2$ & $\mathrm{c} 2$ & SAMA \\
\hline 21 & MIR & $\mathrm{c} 2$ & $\mathrm{c} 2$ & SAMA \\
\hline 22 & MHA & $\mathrm{c} 1$ & $\mathrm{c} 1$ & SAMA \\
\hline 23 & MFA & $\mathrm{c} 2$ & $\mathrm{c} 2$ & SAMA \\
\hline 24 & MZU & $\mathrm{c} 2$ & c3 & BEDA \\
\hline 25 & NIZ & $\mathrm{c} 1$ & $\mathrm{c} 1$ & SAMA \\
\hline 26 & NAP & $\mathrm{c} 2$ & $\mathrm{c} 2$ & SAMA \\
\hline 27 & NIA & $\mathrm{c} 1$ & $\mathrm{c} 2$ & BEDA \\
\hline 28 & NFM & $\mathrm{c} 1$ & $\mathrm{c} 1$ & SAMA \\
\hline 29 & NAA & $\mathrm{c} 2$ & $\mathrm{c} 2$ & SAMA \\
\hline 30 & RNA & $\mathrm{c} 2$ & $\mathrm{c} 2$ & SAMA \\
\hline 31 & SDI & $\mathrm{c} 1$ & $\mathrm{c} 1$ & SAMA \\
\hline 32 & SAY & $\mathrm{c} 2$ & $\mathrm{c} 2$ & SAMA \\
\hline 33 & $\mathrm{VDH}$ & $\mathrm{c} 1$ & $\mathrm{c} 1$ & SAMA \\
\hline 34 & WANA & c3 & c3 & SAMA \\
\hline 35 & WGK & $\mathrm{c} 2$ & $\mathrm{c} 2$ & SAMA \\
\hline
\end{tabular}

Dengan perbandingan yang terdapat pada tabel 5 maka dapat disimpulkan bahwa $89 \%$ memiliki kinerja yang sesuai dengan sistem dan $11 \%$ tidak sesuai dengan sistem. 


\subsection{Pengujian Fungsional}

Tabel 6. Tabel pengujian fungsional

\begin{tabular}{|c|c|c|c|c|c|}
\hline No & Tujuan & Input & Hasil yang diharapkan & Hasil Sistem & Hasil Pengujian \\
\hline 1 & $\begin{array}{l}\text { Menampilkan Nilai } \\
\text { Pengetahuan }\end{array}$ & $\begin{array}{l}\text { - Id Pengetahuan } \\
\text { - Kelas } \\
\text { - Nis } \\
\text { - Guru } \\
\text { - Mata Pelajaran } \\
\text { - Nilai Pengetahuan }\end{array}$ & $\begin{array}{l}\text { Dapat melakukan input serta } \\
\text { menyimpan data ke database } \\
\text { pada table tb_nilaipengetahuan }\end{array}$ & $\begin{array}{l}\text { Tampilan berupa } \\
\text { informasi data yang } \\
\text { telah diinputkan ke } \\
\text { database }\end{array}$ & Sesuai \\
\hline 2 & $\begin{array}{l}\text { Menampilkan Nilai } \\
\text { Keterampilan }\end{array}$ & $\begin{array}{l}\text { - Id Pengetahuan } \\
\text { - Kelas } \\
\text { - Nis } \\
\text { - Guru } \\
\text { - Mata Pelajaran } \\
\text { - Nilai Keterampilan }\end{array}$ & $\begin{array}{l}\text { Dapat melakukan input serta } \\
\text { menyimpan data ke database } \\
\text { pada table tb_nilaiketerampilan }\end{array}$ & $\begin{array}{l}\text { Tampilan berupa } \\
\text { informasi data yang } \\
\text { telah diinputkan ke } \\
\text { database }\end{array}$ & Sesuai \\
\hline 3 & $\begin{array}{l}\text { Menampilkan } \\
\text { Absensi Siswa }\end{array}$ & $\begin{array}{l}\text { - Nis } \\
\text { - Nama Siswa } \\
\text { - Kelas }\end{array}$ & $\begin{array}{l}\text { Dapat melakukan intput serta } \\
\text { menyimpan data ke database } \\
\text { pada table tb_absesnsi }\end{array}$ & $\begin{array}{l}\text { Dapat menampikan } \\
\text { informasi data yang } \\
\text { telah diinputkan ke } \\
\text { database }\end{array}$ & Sesuai \\
\hline 4 & $\begin{array}{l}\text { Menampilkan fitur } \\
\text { dengan Metode K- } \\
\text { Means }\end{array}$ & $\begin{array}{l}\text { - Nis } \\
\text { - Nilai Keterampilan } \\
\text { - Nilai Absensi } \\
\text { - Nilai Sikap } \\
\text { - Nilai Pengetahuan }\end{array}$ & $\begin{array}{l}\text { Dapat melakukan input serta } \\
\text { menyimpan data ke database } \\
\text { pada tb_kmeans }\end{array}$ & $\begin{array}{l}\text { Dapat menampilkan } \\
\text { data yang telah } \\
\text { diinputkan ke database, } \\
\text { serta dapat memproses } \\
\text { perhitungan metode K } \\
\text { Means }\end{array}$ & Sesuai \\
\hline 5 & $\begin{array}{l}\text { Menampilakan fitur } \\
\text { Report data Nilai }\end{array}$ & $\begin{array}{l}\text { - Kelas } \\
\text { - Siswa }\end{array}$ & $\begin{array}{l}\text { Dapat menampilkan data siswa } \\
\text { dengan semua nilai yang } \\
\text { mereka peroleh dari nilai } \\
\text { keterampilan, nilai } \\
\text { pengetahuan, nilai sikap, dan } \\
\text { absensi siswa. Serta dapat } \\
\text { mendownload data nilai siswa } \\
\text { tersebut }\end{array}$ & $\begin{array}{l}\text { Tampilan berupa data } \\
\text { siswa yang memiliki } \\
\text { nilai yang diperoleh } \\
\text { seperti nilai } \\
\text { pengetahuan, nilai } \\
\text { keterampilan, nilai } \\
\text { sikap, serta absensi } \\
\text { siswa }\end{array}$ & Sesuai \\
\hline
\end{tabular}

\subsection{Pengujian Browser}

Pengujian software pada penelitian ini dengan dilakukannya menguji kompabilitas website terhadap web browser yang bertujuan untuk mengetahui apakah halaman website yang dibuat dapat menampilkan keseluruhan data sesuai dengan perancangan bukan hanya pada satu web browser yang sering digunakan pada umumnya. Hasil uji coba kompabilitas website terhadap web browser seperti ditunjukan pada Tabel 7, untuk versi dari Google Chrome 91.0.4472.106 (Official Build) (64-bit), untuk versi dari Microsoft Edge 91.0.864.54 (Official build) (64-bit), untuk versi dari Mozilla Firefox 89.

Tabel 7. Software Sistem

\begin{tabular}{|c|l|c|c|c|}
\hline \multirow{2}{*}{ No } & \multicolumn{1}{|c|}{ Aspek } & \multicolumn{3}{|c|}{ Web Browser } \\
\cline { 3 - 5 } & Chrome & $\begin{array}{c}\text { Miscosoft } \\
\text { Edge }\end{array}$ & $\begin{array}{c}\text { Mozilla } \\
\text { Firefox }\end{array}$ \\
\hline 1 & $\begin{array}{l}\text { Menampilkan Nilai } \\
\text { Pengetahuan }\end{array}$ & $\sqrt{ }$ & $\sqrt{ }$ & $\sqrt{ }$ \\
\hline 2 & $\begin{array}{l}\text { Menampilkan Nilai } \\
\text { Keterampilan }\end{array}$ & $\sqrt{ }$ & $\sqrt{ }$ & $\sqrt{ }$ \\
\hline 3 & $\begin{array}{l}\text { Menampilkan } \\
\text { Absensi Siswa }\end{array}$ & $\sqrt{ }$ & $\sqrt{ }$ & $\sqrt{ }$ \\
\hline 4 & $\begin{array}{l}\text { Menampilkan Nilai } \\
\text { Sikap }\end{array}$ & $\sqrt{ }$ & $\sqrt{ }$ & $\sqrt{ }$ \\
\hline 5 & $\begin{array}{l}\text { Menampilkan Proses } \\
\text { metode K-Means }\end{array}$ & $\sqrt{ }$ & $\sqrt{ }$ & $\sqrt{ }$ \\
\hline
\end{tabular}

Keterangan :

$\quad \sqrt{ }:$ Berhasil
$X:$ Gagal

\subsection{Pengujian User}

Pengujian user diperlukan untuk mengetahui tingkat kepuasan pengguna terhadap pengalaman pengguna dan tampilan antarmuka aplikasi. Pengujian dilakukan terhadap 5 guru mata pelajaran yang terkait, pertanyaan mengenai pengalaman pengguna ketika mengoperasikan aplikasi.

Dalam menentukan hasil persentase kuesioner menggunakan rumus mencari persentase hasil kuesioner seperti pada persamaan berikut (Sugiyono, 2008) :

Persamaan

$$
\rho=f / n \times 100
$$

Dimana :

$\mathrm{p}:$ Presentase

f : Jumlah jawaban

$\mathrm{n}$ : Jumlah responden

Berdasarkan hasil dari pengisihan kuesioner yang didapatkan penulis dari responden dan dihitung jumlah keseluruhannya mendapatkan persentase hasil seperti berikut, dapat dilihat pada Tabel 8 .

Tabel 8. Tabel Pengujian User

\begin{tabular}{|c|l|c|c|c|}
\hline \multirow{2}{*}{ No } & \multicolumn{1}{|c|}{ Pertanyaan } & $\begin{array}{c}\text { Setuju } \\
(\mathbf{S})\end{array}$ & $\begin{array}{c}\text { Kurang } \\
\text { Setuju } \\
(\text { KS })\end{array}$ & $\begin{array}{c}\text { Tidak } \\
\text { Setuju } \\
\text { (TS) }\end{array}$ \\
\hline \multirow{2}{*}{1} & $\begin{array}{l}\text { Apakah web mudah } \\
\text { dipahami dalam } \\
\text { pemakaian? }\end{array}$ & $(4)$ & $(1)$ & $(0)$ \\
\hline 2 & $\begin{array}{l}\text { Apakah tombol mudah } \\
\text { dijangkau? }\end{array}$ & $(4)$ & $20 \%$ & $0 \%$ \\
\hline 3 & Apakah alur menu pada & $(4)$ & $(1)$ & $(0)$ \\
\hline
\end{tabular}




\begin{tabular}{|c|l|c|c|c|}
\hline & $\begin{array}{l}\text { program mudah } \\
\text { dipahami? }\end{array}$ & $80 \%$ & $10 \%$ & $0 \%$ \\
\hline \multirow{5}{*}{4} & $\begin{array}{l}\text { Apakah form-form yang } \\
\text { ada pada aplikasi sudah } \\
\text { jelas dan mudah } \\
\text { digunakan? }\end{array}$ & $\begin{array}{c}(4) \\
80 \%\end{array}$ & $\begin{array}{c}(0) \\
0 \%\end{array}$ & $\begin{array}{c}(1) \\
5 \%\end{array}$ \\
\hline \multirow{5}{5}{5} & $\begin{array}{l}\text { Apakah kriteria data } \\
\text { yang digunakan sesuai } \\
\text { dengan kriteria data nilai } \\
\text { siswa? }\end{array}$ & $\begin{array}{c}(5) \\
100 \%\end{array}$ & $(0)$ & $(0)$ \\
\hline
\end{tabular}

Pada tabel 8, dapat dijelaskan bahwa pengujian pada user dari 25 user dalam perhitungan. Pertanyaan mengenai ukuran dan warna font dengan hasil S:4, KS:1, TS:0. Pertanyaan mengenai tombol dan background dengan hasil S:4, KS:1, TS:0. Pertanyaan mengenai alur menu dengan hasil S:5, KS:0, TS:0. Pertanyaan mengenai form dengan hasil S:4, KS:0, TS:1. Pertanyaan mengenai kriteria dengan hasil S:5, KS:0, TS:0. Dijumlahkan pemilihan S:21, KS:3, TS:1. Dibagi dengan jumlah seluruh pilihan : $5 \times 5=$ 25. Pemilih S: $21 / 25 \times 100=84 \%$. Pemilihan KS: $3 / 25 \times 100=12 \%$. Pemilihan TS: $1 / 25 \times 100=4 \%$.

\section{KESIMPULAN DAN SARAN}

\subsection{Kesimpulan}

Kesimpulan yang dapat penulis sampaikan setelah penelitian ini antara lain yaitu :

1. Rerata presentasi sistem error sebesar $12 \%$ sehingga dapat diketahui penerapan metode KMeans untuk pengelompokkan siswa berprestasi sebesar $88 \%$.

2. User memberi penilaian setuju untuk 5 aspek sebesar $84 \%$, kurang setuju 3 untuk 3 aspek sebesar $12 \%$, dan tidak setuju untuk 1 aspek sebesar $4 \%$.

3. Aplikasi ini dapat berjalan baik dan dapat menampilkan keseluruhan data pada Google Chrome 91.0.4472.106 (Official Build) (64-bit), untuk versi dari Microsoft Edge 91.0.864.54 (Official build) (64-bit), untuk versi dari Mozilla Firefox versi 88.0.1 (64-bit).

4. Data yang dikelompokkan pada c1 berjumlah 14 orang, sedangkan untuk data yang dikelompokkan pada c2 berjumlah 16 orang dan yang terakhir yaitu data yang dikelompokkan pada c3 berjumlah 5 orang pada mata pelajaran Bahasa Jerman.

\subsection{Saran}

Saran pengembangan untuk Sistem Informasi Akademik untuk menentukan siswa berprestasi yaitu:

1. Diharapkan kedepannya aplikasi ini dapat berjalan di mobile yang dapat dipantau setiap saat.
2. Diharapkan aplikasi dapat login melalui akun google yang telah terdaftar.

3. Diaharapkan aplikasi dapat menampilkan bentuk diagram lain sebagai visualisasi data dari attribut atau karakteristik user.

4. Diharapkan aplikasi ini dapat menjadi fleksible dan efisien kedepannya mengikuti dari cara penilaian yang baru.

\section{DAFTAR PUSTAKA}

[1] Fitri Larasati Sibeua, A. S. (2017). Pemetaan Siswa Berprestasi Menggunakan Metode $K$ Means Clustering, 85-92.

[2] Tedy Rismawan, S. K. (2008). Aplikasi KMeans untuk Pengelompokkan Mahasiswa Berdasarkan Nilai Body Mass Index (BMI) \& Ukuran Kerangka, E 45-E 47.

[3] Niagahoster.com (25 Mei 2019). Pengertian JQuery Serta Fungsi dan Contohnya. Diakses pada 30 Januari 2021, pada https://www.niagahoster.co.id/blog/jqueryadalah/

[4] Hostinger.co.id (10 April 2019). Apa Itu JQuery. Diakses pada 10 Februari 2021, pada https://www.hostinger.co.id/tutorial/apa-ituiquery/

[5] Nawang Galuh Safitri, d. (2021). Dampak Pandemi Covid-19 Terhadap Penerapan Pembelajaran Daring di Sekolah Dasar.

[6] Qwords.com (19 September 2019). Pengertian XAMPP Lengkap dengan Fungsi dan Cara Instalasi.. Diakses pada 10 Februari 2021, pada : https://qwords.com/blog/pengertian-xampp/

[7] Termasmedia.com (16 Juli 2019). Mengenal phpMyAdmin dan Kegunaannya.. Diakses pada 10 Feburari 2021, pada : https://www.termasmedia.com/database/phpmya dmin/131-mengenal-phpmyadmin-dankegunaannya.html

[8] www.nesabamedia.com (3 September 2021). pengertian-framework. Diakses pada 10 Februari 2021: https://www.nesabamedia.com/pengertianframework/

[9] www.ansoriweb.com (28 March 2020).Pengertian DFD (Data Flow Diagram) : Fungsi, Simbol, dan Contohnya. Diakses 11 Agustus 2021: https://www.ansoriweb.com/2020/03/pengertian -dfd.html

[10] Qwords.com (17 Desember 2019). Mengenal Apa Itu DFD Serta Contohnya. diakses pada 11 Agustus 2021 https://qwords.com/blog/apa-itudfd-dan-contoh/ 